\title{
Association of the GLB1 rs4678680 genetic variant with risk of HBV-related hepatocellular carcinoma
}

\author{
Wen-Tao Wang ${ }^{1, *}$, Ziqiang Li', ${ }^{1,}$ Meng Shi' ${ }^{2,3}$, Hui Zhu ${ }^{4}$, Xiangyu Xiong ${ }^{3}$, Jinhua \\ Shang ${ }^{3}$, Jibing Liu ${ }^{5}$, Mujian Teng ${ }^{1}$, Ming Yang ${ }^{2}$ \\ ${ }^{1}$ Department of Hepatobiliary Surgery, Qianfoshan Hospital, Shandong University, Jinan, Shandong Province, China \\ ${ }^{2}$ Shandong Provincial Key Laboratory of Radiation Oncology, Cancer Research Center, Shandong Cancer Hospital affiliated to \\ Shandong University, Shandong Academy of Medical Sciences, Jinan, Shandong Province, China \\ ${ }^{3}$ College of Life Science and Technology, Beijing University of Chemical Technology, Beijing, China \\ ${ }^{4}$ Department of Radiation Oncology, Shandong Cancer Hospital Affiliated to Shandong University, Shandong Academy of \\ Medical Sciences, Jinan, Shandong Province, China \\ ${ }^{5}$ Department of Intervention Surgery, Shandong Cancer Hospital Affiliated to Shandong University, Shandong Academy of \\ Medical Sciences, Jinan, Shandong Province, China \\ ${ }^{*}$ These authors contributed equally to this work
}

Correspondence to: Ming Yang, email: aaryoung@yeah.net

Keywords: GLB1, genetic polymorphism, HBV, HCC, susceptibility

Received: June 13, 2016 Accepted: July 19, $2016 \quad$ Published: July 30, 2016

\section{ABSTRACT}

Accumulated evidences demonstrated that GLB1 is involved in cell senescence and cancer development. The GLB1 rs4678680 single nucleotide polymorphism (SNP) has been identified as a hepatocellular carcinoma (HCC) susceptibility polymorphism by a genome-wide association study in Korean population previously. However, little or nothing was known about its involvement and functional significance in hepatitis B viruses (HBV)-related HCC in Chinese. Therefore, we investigated the association between the GLB1 rs4678680 SNP and HBV-related HCC risk as well as its biological function in vivo. Genotypes were determined in two independent case-control sets from two medical centers of China. Odds ratios (ORs) and $95 \%$ confidence intervals (CIs) were estimated by logistic regression. The potential regulation role the rs4678680 genetic variant on GLB1 expression was examined with HCC and normal liver tissues. We found that The rs4678680 $\mathrm{G}$ allele was showed to be risk allele; individuals with the TG genotype had an OR of 1.51 (95\% CI $=1.10-2.07, P=0.010$, Shandong set) or 1.49 (95\% CI $=1.11-1.99, P=0.008$, Jiangsu set) for developing HBV-related HCC, respectively, compared with individuals with the TT genotype. This association was more pronounced in males, individuals aged older than $\mathbf{5 7}$ years and drinkers (all $P<0.05$ ). In the genotype-phenotype correlation analyses of fifty-six human liver tissue samples, rs4678680 TG or GG was associated with a statistically significant increase of GLB1 mRNA expression $(P<0.05)$. Our data indicated that the GLB1 rs4678680 SNP contributes to susceptibility to develop HBV-related HCC, highlighting the involvement of GLB1 and cell senescence in etiology of HCC.

\section{INTRODUCTION}

Although ranking the fifth most common cancer, hepatocellular carcinoma (HCC) is the third leading cause of cancer-related mortality worldwide [1]. There is a high incidence of HCC in China and other AsiaPacific region [1]. Notably, China alone accounts for about $50 \%$ of all HCC cases in the world [1,2]. There were several epidemiological features, such as marked variations between geographical regions, racial and ethnic groups, and sex. It has been revealed that men have a higher prevalence of HCC than women, i.e. the male:female ratio of HCC patients is $\sim 2.65: 1$ in highrisk Chinese populations [2,3]. Chronic infections with 
the hepatitis $\mathrm{B}$ or $\mathrm{C}$ viruses (HBV or $\mathrm{HCV}$ ), exposure to dietary aflatoxin $\mathrm{B}$ as well as excessive alcohol drinking have been identified as major environmental risk factors of HCC $[2,3]$. Since about $75 \%$ cases of HCC are associated with $\mathrm{HBV}$ infection in China [4], $\mathrm{HBV}$ infection is considered as one major risk factor for HCC. However, only $15 \%$ chronic HBV carriers suffer from HCC in their lifetime $[2,3]$, indicating that host genetic factors may also be involved in development of HBV-related HCC. This notion has been proved by several candidate gene and genome-wide association study (GWAS) on HBV-related HCC in eastern Asians [5-10].

To identify genetic factors associated with $\mathrm{HCC}$, Clifford et al. conducted a comprehensive, genome-wide variation analysis (both genetic polymorphisms and copy number variations) in a population of unrelated Asian individuals [11]. After genotyping 386 Korean HCC cases and 587 Korean controls with the Affymetrix SNP6.0 assay, they found that the $3 \mathrm{p} 21.33$ GLB1 rs4678680 $\mathrm{G}>\mathrm{T}$ polymorphism is most significantly associated with $\mathrm{HCC}$ risk (odds ratio $[\mathrm{OR}]=2.27,95 \%$ confidence intervals $\left.[\mathrm{CI}]=1.68-3.08, P=6 \times 10^{-7}\right)$. GLB1 encodes a member of the glycosyl hydrolase 35 family of proteins, which catalyzes the hydrolysis of a terminal betalinked galactose residue from ganglioside substrates and other glycoconjugates. Accumulated evidences demonstrated that GLB1 is involved in cell senescence $[12,13]$ and cancer development [13-16]. Senescence phenotype could be induced by increased SA-b-galactosidase staining and elevated $G L B 1 \mathrm{mRNA}$ expression, indicating the important role of GLB1 in cell senescence. During the long latency of tumor development, oncogene-induced senescence has emerged as a barrier to tumorigenesis including HCC. Chen et al. conducted a replication casecontrol study on the association of $1 \mathrm{p} 36.22,2 \mathrm{q} 32.2-\mathrm{q} 32.3$, 3 p21.33, 8p12, 14q32.11 and 21q21.3 with HCC among 507 Chinese HCC patients and 3014 Chinese controls. However, they did not included GLB1 rs4678680 G > $\mathrm{T}$ single nucleotide polymorphism (SNP) in the study. As a result, it is still largely unclear if GLB1 rs4678680 polymorphism plays a part in etiology of HCC in Chinese. Also, little or nothing has been known about functional significance of the GLB1 rs4678680 SNP in HBV-related HCC. Therefore, we conducted two large independent case-control studies to investigate the association between the GLB1 rs4678680 genetic polymorphism and risk for developing HBV-related HCC. To validate the biological function of the rs4678680 SNP in vivo, we examined the association between GLB1 rs4678680 genotypes and its mRNA expression levels in normal liver tissues.

\section{RESULTS}

Allele frequencies and genotype distributions of GLB1 rs4678680 SNP in cases and controls from the Shandong and Jiangsu sets are showed in Table 1. The allele frequencies for rs $4678680 \mathrm{G}$ were 0.087 or 0.094 in cases and 0.059 or 0.058 in controls in Shandong or Jiangsu case-control set. All observed genotype frequencies in both cases and controls conform to HardyWeinberg equilibrium. Distributions of the rs4678680 genotypes were compared between HCC cases and controls. Frequencies of rs4678680 TT, TG and GG genotypes among HCC cases differed significantly from those among controls in either Shandong set $\left(\chi^{2}=7.593, P=0.022, d f=2\right)$ or Jiangsu set $\left(\chi^{2}=16.14\right.$, $\left.P=3.12 \times 10^{-4}, d f=2\right)$.

Unconditional logistic regression analysis was used to examine associations between the GLB1 rs4678680 SNP and HBV-related HCC risk in Shandong and Jiangsu sets (Table 1). The rs4678680 $\mathrm{G}$ allele was showed to be risk allele; individuals with the TG genotype had an OR of 1.51 (95\% CI $=1.10-2.07, P=0.010$, Shandong set) or $1.49(95 \% \mathrm{CI}=1.11-1.99, P=0.008$, Jiangsu set $)$ for developing HBV-related HCC, respectively, compared with individuals with the TT genotype (Table 1). It was also found that carriers of the rs4678680 TG or GG genotype showed significantly and consistently increased risk to develop HBV-related HCC compared with the TT carriers in both case-control sets (Shandong set: $\mathrm{OR}=1.53,95 \% \mathrm{CI}=1.12-2.10, P=0.007$; Jiangsu set: $\mathrm{OR}=1.57,95 \% \mathrm{CI}=1.18-2.09, P=0.002)$. In the pooled analyses, we observed that the odds of having the rs4678680 TG genotype in cases was $1.56(95 \%$ $\left.\mathrm{CI}=1.24-1.97, P=1.76 \times 10^{-4}\right)$ compared with the TT genotype. Similarly, the rs4678680 TG or GG genotype carriers showed a 1.52-fold increased HCC risk compared with the TT genotype carriers $(95 \% \mathrm{CI}=1.19-1.94$, $P=0.001)$.

The risk of HBV-related HCC associated with the GLB1 rs4678680 genotypes was further examined by stratifying for sex (Table 2). A significantly increased risk of HCC associated with the rs4678680 TG or GG genotype compared with the TT genotype was observed in males (Shandong set: $\mathrm{OR}=1.60,95 \% \mathrm{CI}=1.15-2.23$; $P=0.006$; Jiangsu set: $\mathrm{OR}=1.59,95 \% \mathrm{CI}=1.17-2.16$; $P=0.003)$. However, this genetic polymorphism was not significantly associated with HCC risk in females (all $P>0.05)$. In the stratification analyses with age, elevated risk of HCC associated with the GLB1 rs4678680 TG or GG genotype was only observed among individuals aged older than 57 years (Shandong set: OR $=1.63,95 \%$ $\mathrm{CI}=1.01-2.62 ; P=0.047)$, but not among individuals aged 57 years or younger (Shandong set: OR $=1.46,95 \%$ $\mathrm{CI}=0.96-2.21 ; P=0.076$ ) (Table 3 ). Similar results were observed among individuals aged older than 57 years in Jiangsu set (rs4678680 TG or GG genotype: OR $=2.10$, $95 \% \mathrm{CI}=1.37-3.21 ; P=0.001)$. Interestingly, the rs4678680 TG or GG genotype was also significantly associated with increased HCC risk in drinkers compared to the TT genotype in both sets (Shandong: OR $=1.90$, 95\% CI $=1.26-2.86, P=0.002$; Jiangsu: OR $=1.76$, 
Table 1: Genotype frequencies of the $G L B 1$ rs4678680 G > T polymorphism among HCC cases and chronic HBV carriers and its association with $\mathrm{HBV}$-related HCC risk

\begin{tabular}{|c|c|c|c|c|c|}
\hline Studies & Genotypes & $\begin{array}{c}\text { HCC cases } \\
\text { No. }(\%)\end{array}$ & $\begin{array}{c}\text { Chronic HBV } \\
\text { carriers No. (\%) }\end{array}$ & OR $^{\mathrm{a}}(95 \% \mathrm{CI})$ & $P$-value ${ }^{a}$ \\
\hline \multirow{5}{*}{ Shandong set } & & $n=1186$ & $n=508$ & & \\
\hline & TT & $987(83.2)$ & 449 (88.4) & Reference & \\
\hline & TG & $192(16.2)$ & $58(11.4)$ & $1.51(1.10-2.07)$ & 0.010 \\
\hline & GG & $7(0.6)$ & $1(0.2)$ & $\mathrm{NC}$ & \\
\hline & $\mathrm{TG}+\mathrm{GG}$ & $199(16.8)$ & 59 (11.6) & $1.53(1.12-2.10)$ & 0.007 \\
\hline \multirow{5}{*}{ Jiangsu set } & & $n=620$ & $n=1200$ & & \\
\hline & $\mathrm{TT}$ & $509(82.1)$ & $1062(88.4)$ & Reference & \\
\hline & $\mathrm{TG}$ & 105 (16.9) & $136(11.3)$ & $1.49(1.11-1.99)$ & 0.008 \\
\hline & GG & $6(1.0)$ & $2(0.2)$ & $\mathrm{NC}$ & \\
\hline & $\mathrm{TG}+\mathrm{GG}$ & $111(17.9)$ & $138(11.5)$ & $1.57(1.18-2.09)$ & 0.002 \\
\hline \multirow{5}{*}{ Pooled } & & $n=1806$ & $n=1708$ & & \\
\hline & $\mathrm{TT}$ & $1496(82.8)$ & $1511(88.5)$ & Reference & \\
\hline & $\mathrm{TG}$ & $297(16.5)$ & $194(11.4)$ & $1.56(1.24-1.97)$ & $1.76 \times 10^{-4}$ \\
\hline & GG & $13(0.7)$ & $3(0.2)$ & $\mathrm{NC}$ & \\
\hline & $\mathrm{TG}+\mathrm{GG}$ & $310(17.2)$ & $197(11.6)$ & $1.52(1.19-1.94)$ & 0.001 \\
\hline
\end{tabular}

Note: HBV, hepatitis B virus; HCC, hepatocellular carcinoma; OR, odds ratio; CI, confidence interval; NC, not calculated. ${ }^{a} \mathrm{HCC}$ case vs. chronic HBV carriers, data were calculated by logistic regression with adjustment for age, sex, smoking and drinking.

$95 \% \mathrm{CI}=1.21-2.57, P=0.003)$ (Table 4). However, no such associations was observed among non-drinkers (all $P>0.05)$.

We next examined whether the HCC susceptibility SNP rs4678680 has an allele-specific impact on GLB1 expression using HCC tissues since it locates in a $18 \mathrm{~kb}$ upstream region of GLB1. As shown in Figure 1, we found that there were significantly higher GLB1 mRNA levels (mean $\pm \mathrm{SD}$ ) in HCC tissues compared to normal tissues $(313.3 \pm 33.93$ vs. $189.9 \pm 21.1 ; P=0.003)$. Subjects with the rs $4678680 \mathrm{TG}$ or GG genotype had significantly higher GLB1 mRNA levels than those with the TT genotypes in normal tissues (TG or GG: $367.5 \pm 40.2[n=9]$, TT: $155.9 \pm 20.6[n=47] ; P=0.001)$. Similar results were observed when the GLB1 mRNA levels were compared between rs4678680 TG or GG and TT genotypes in HCC tissues (TG or GG: $590.7 \pm 32.2[n=9]$, TT: $260.1 \pm 35.0$ $[n=47] ; P=0.001)$ (Figure 1).

\section{DISCUSSION}

In the current study, we examined the association between the GLB1 rs4678680 SNP and risk of developing $\mathrm{HBV}$-related $\mathrm{HCC}$ in a case-control design. Although the genetic predisposition to HCC of the GLB1 rs4678680 polymorphism was firstly identified in Korean populations via GWAS, this is still the first validation study with relative large sample size in different ethnic populations.
We found significantly increased HCC risk among individuals with the GLB1 rs4678680 TG or GG genotype compared with those with TT genotype in Chinese. In the genotype-phenotype correlation analyses of fifty-six human liver tissue samples, rs4678680 TG or GG was associated with a statistically significant increase of GLB1 mRNA expression.

The GLB1 gene provides instructions for producing an enzyme called $\beta$-galactosidase. This enzyme is located in lysosomes, which are compartments within cells that break down and recycle different types of molecules. Within lysosomes, GLB1 helps break down certain molecules, including substances called GM1 ganglioside and keratan sulfate. Caldwell et al. found that GLB1 activity is the only biomarker that accurately identifies a small and heterogeneous population of nonproliferating premalignant cells in the pancreas, indicating the utility of GLB1 to predict the senescent state in pancreatic preneoplasia [13]. Additionally, increased GLB1 is a valuable marker in formalin-fixed paraffinembedded tissues for the senescence-like phenotype and associates with improved prostate cancer outcomes [16]. All these evidences support the involvement of GLB1 in carcinogenesis, possibly through regulating cell senescence.

Several limitations may exist in this case-control study. First, because it was a hospital-based study and the cases were from hospitals, there might be inherent 
Table 2: Risk of HBV-related HCC associated with GLB1 rs4678680 G > T genotypes by sex

\begin{tabular}{|c|c|c|c|c|c|c|c|c|c|}
\hline \multirow[b]{2}{*}{ Studies } & \multirow[b]{2}{*}{ Genotypes } & \multicolumn{3}{|c|}{ Males } & \multicolumn{5}{|c|}{ Females } \\
\hline & & $\begin{array}{c}\text { Cases } \\
\text { No. }(\%)\end{array}$ & $\begin{array}{l}\text { Controls } \\
\text { No. }(\%)\end{array}$ & $\begin{array}{c}\text { OR }^{\mathrm{a}} \\
(95 \% \mathrm{CI})\end{array}$ & $P$-value ${ }^{a}$ & $\begin{array}{c}\text { Cases } \\
\text { No. }(\%)\end{array}$ & $\begin{array}{l}\text { Controls } \\
\text { No. }(\%)\end{array}$ & $\begin{array}{c}\mathrm{OR}^{\mathrm{a}} \\
(95 \% \mathrm{CI})\end{array}$ & $P$-value ${ }^{a}$ \\
\hline \multirow{5}{*}{ Shandong set } & & $n=1018$ & $n=425$ & & & $n=168$ & $n=83$ & & \\
\hline & TT & $848(83.3)$ & $373(87.8)$ & Reference & & $139(82.7)$ & $76(91.6)$ & Reference & \\
\hline & TG & $164(16.1)$ & $51(12.0)$ & $1.58(1.13-2.21)$ & 0.008 & $28(16.7)$ & $7(8.4)$ & $\begin{array}{c}1.39 \\
(0.54-3.60)\end{array}$ & 0.500 \\
\hline & GG & $6(0.6)$ & $1(0.2)$ & $\mathrm{NC}$ & & $1(0.6)$ & $0(0)$ & $\mathrm{NC}$ & \\
\hline & $\mathrm{TG}+\mathrm{GG}$ & $170(16.7)$ & $52(12.2)$ & $1.60(1.15-2.23)$ & 0.006 & $29(17.3)$ & $7(8.4)$ & $\begin{array}{c}1.47 \\
(0.57-3.77)\end{array}$ & 0.428 \\
\hline \multirow{5}{*}{ Jiangsu set } & & $n=531$ & $n=998$ & & & $n=89$ & $n=202$ & & \\
\hline & $\mathrm{TT}$ & $437(82.3)$ & $884(88.6)$ & Reference & & $72(80.9)$ & $178(88.1)$ & Reference & \\
\hline & TG & 88 (16.6) & $112(11.2)$ & $1.50(1.11-2.05)$ & 0.011 & $17(19.1)$ & $24(11.9)$ & $\begin{array}{c}1.36 \\
(0.38-4.83)\end{array}$ & 0.639 \\
\hline & GG & $6(1.1)$ & $2(0.2)$ & $\mathrm{NC}$ & & $0(0)$ & $0(0)$ & $\mathrm{NC}$ & \\
\hline & $\mathrm{TG}+\mathrm{GG}$ & $94(17.7)$ & $114(11.4)$ & $1.59(1.17-2.16)$ & 0.003 & $17(19.1)$ & $24(11.9)$ & $\begin{array}{c}1.36 \\
(0.38-4.83)\end{array}$ & 0.639 \\
\hline
\end{tabular}

Note: HBV, hepatitis B virus; HCC, hepatocellular carcinoma; OR, odds ratio; CI, confidence interval; NC, not calculated. ${ }^{a} \mathrm{HCC}$ case vs. chronic HBV carriers, data were calculated by logistic regression with adjustment for age, smoking and drinking.

A

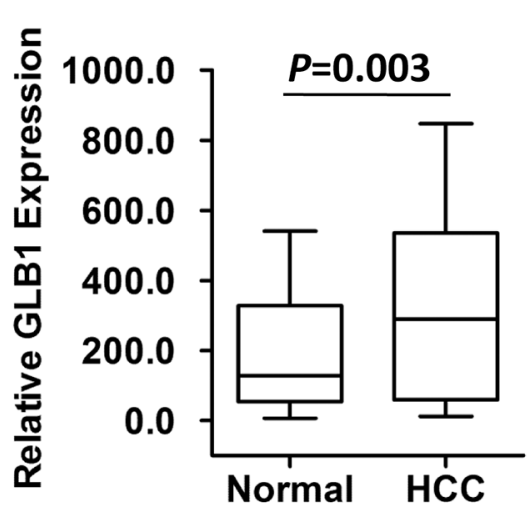

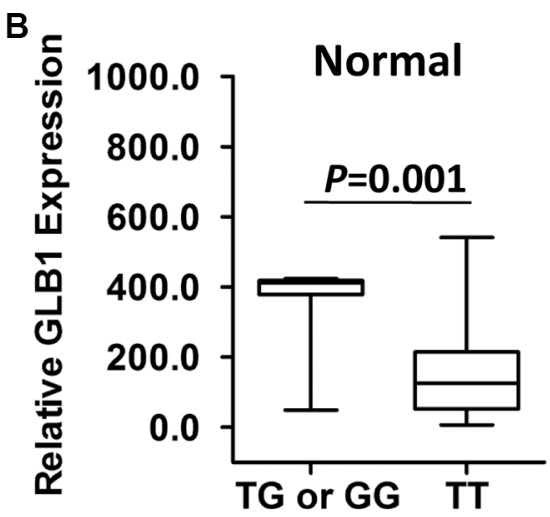

C

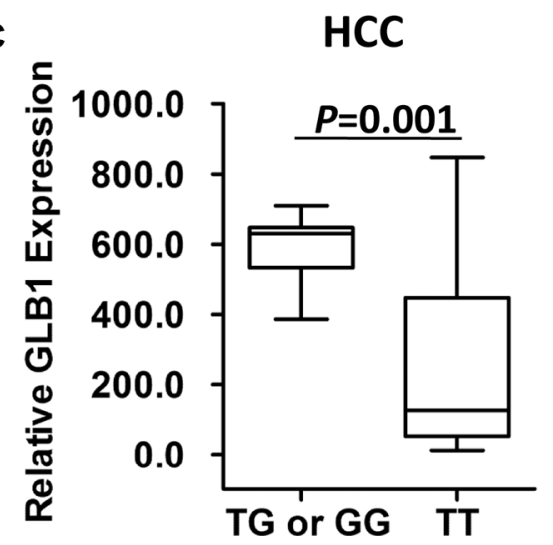

Figure 1: GLB1 mRNA expression in fifty-six pairs of HCC-normal liver tissues. (A) There were higher $G L B 1$ mRNA expression in HCC tissues than those in normal liver tissues. (B) GLB1 mRNA expression in normal liver tissues grouped by GLB1 rs4678680 genotypes. (C) GLB1 mRNA expression in HCC tissues grouped by GLB1 rs4678680 genotypes. 
Table 3: Risk of HBV-related HCC associated with $G L B 1$ rs4678680 G > T genotypes by age

\begin{tabular}{|c|c|c|c|c|c|c|c|c|c|}
\hline \multirow[b]{2}{*}{ Studies } & \multirow[b]{2}{*}{ Genotypes } & \multicolumn{2}{|r|}{ Age } & \multicolumn{2}{|l|}{ ( $\leq 57$ years) } & \multicolumn{2}{|r|}{ Age } & \multicolumn{2}{|l|}{ ( $>57$ years) } \\
\hline & & $\begin{array}{c}\text { Cases } \\
\text { No. }(\%)\end{array}$ & $\begin{array}{l}\text { Controls } \\
\text { No. }(\%)\end{array}$ & $\begin{array}{c}\mathrm{OR}^{\mathrm{a}} \\
(95 \% \mathrm{CI})\end{array}$ & $P$-value & $\begin{array}{c}\text { Cases } \\
\text { No. }(\%)\end{array}$ & $\begin{array}{l}\text { Controls } \\
\text { No. }(\%)\end{array}$ & $\begin{array}{c}\mathrm{OR}^{\mathrm{a}} \\
(95 \% \mathrm{CI})\end{array}$ & $P$-value ${ }^{a}$ \\
\hline \multirow{5}{*}{ Shandong set } & & $n=627$ & $n=262$ & & & $n=559$ & $n=246$ & & \\
\hline & TT & $516(82.3)$ & $228(87.0)$ & Reference & & $471(84.3)$ & $221(89.8)$ & Reference & \\
\hline & TG & $108(17.2)$ & 33 (12.6) & $\begin{array}{c}1.46 \\
(0.96-2.23)\end{array}$ & 0.077 & $84(15.0)$ & $25(10.2)$ & $\begin{array}{c}1.56 \\
(0.96-2.51)\end{array}$ & 0.072 \\
\hline & GG & $3(0.5)$ & $1(0.4)$ & $\mathrm{NC}$ & & $4(0.7)$ & $0(0)$ & $\mathrm{NC}$ & \\
\hline & $\mathrm{TG}+\mathrm{GG}$ & $111(17.7)$ & $34(13.0)$ & $\begin{array}{c}1.46 \\
(0.96-2.21)\end{array}$ & 0.076 & 88 (15.7) & $25(10.2)$ & $\begin{array}{c}1.63 \\
(1.01-2.62)\end{array}$ & 0.047 \\
\hline \multirow{5}{*}{ Jiangsu set } & & $n=315$ & $n=633$ & & & $n=305$ & $n=567$ & & \\
\hline & TT & $265(84.1)$ & $552(87.2)$ & Reference & & $244(80.0)$ & $510(89.9)$ & Reference & \\
\hline & TG & $44(14.0)$ & $79(12.5)$ & $\begin{array}{c}1.06 \\
(0.70-1.60)\end{array}$ & 0.791 & $61(20.0)$ & $57(10.1)$ & $\begin{array}{c}2.10 \\
(1.37-3.21)\end{array}$ & 0.001 \\
\hline & GG & $6(1.9)$ & $2(0.3)$ & $\mathrm{NC}$ & & $0(0)$ & $0(0)$ & $\mathrm{NC}$ & \\
\hline & $\mathrm{TG}+\mathrm{GG}$ & $50(15.9)$ & $81(12.8)$ & $\begin{array}{c}1.19 \\
(0.80-1.78)\end{array}$ & 0.388 & $61(20.0)$ & $57(10.1)$ & $\begin{array}{c}2.10 \\
(1.37-3.21)\end{array}$ & 0.001 \\
\hline
\end{tabular}

Note: HBV, hepatitis B virus; HCC, hepatocellular carcinoma; OR, odds ratio; CI, confidence interval; NC, not calculated. ${ }^{a} \mathrm{HCC}$ case vs. chronic HBV carriers, data were calculated by logistic regression with adjustment for sex, smoking and drinking.

Table 4: Risk of HBV-related HCC associated with GLB1 rs4678680 G > T genotypes by alcohol drinking

\begin{tabular}{|c|c|c|c|c|c|c|c|c|c|}
\hline \multirow[b]{2}{*}{ Studies } & \multirow[b]{2}{*}{ Genotypes } & \multicolumn{3}{|c|}{ Nondrinkers } & \multirow[b]{2}{*}{$P$-value ${ }^{\text {a }}$} & \multicolumn{3}{|c|}{ Drinkers } & \multirow[b]{2}{*}{$P$-value } \\
\hline & & $\begin{array}{c}\text { Cases } \\
\text { No. }(\%)\end{array}$ & $\begin{array}{l}\text { Controls } \\
\text { No. }(\%)\end{array}$ & $\begin{array}{c}\mathrm{OR}^{\mathrm{a}} \\
(95 \% \mathrm{CI})\end{array}$ & & $\begin{array}{c}\text { Cases } \\
\text { No. }(\%)\end{array}$ & $\begin{array}{l}\text { Controls } \\
\text { No. }(\%)\end{array}$ & $\begin{array}{c}\mathrm{OR}^{\mathrm{a}} \\
(95 \% \mathrm{CI})\end{array}$ & \\
\hline \multirow{5}{*}{ Shandong set } & & $n=410$ & $n=195$ & & & $n=776$ & $n=313$ & & \multirow[b]{3}{*}{0.004} \\
\hline & $\mathrm{TT}$ & $349(85.1)$ & $168(86.2)$ & Reference & & $638(82.2)$ & $281(89.8)$ & Reference & \\
\hline & TG & $59(14.4)$ & $26(13.3)$ & $1.16(0.70-1.92)$ & 0.578 & $133(17.2)$ & $32(10.2)$ & $\begin{array}{c}1.82 \\
(1.21-2.75)\end{array}$ & \\
\hline & GG & $2(0.5)$ & $1(0.5)$ & $\mathrm{NC}$ & & $5(0.6)$ & $0(0)$ & $\mathrm{NC}$ & \multirow{3}{*}{0.002} \\
\hline & \multirow[t]{2}{*}{$\mathrm{TG}+\mathrm{GG}$} & $61(14.9)$ & $27(13.8)$ & $1.14(0.69-1.87)$ & 0.620 & $138(17.8)$ & $32(10.2)$ & $\begin{array}{c}1.90 \\
(1.26-2.86)\end{array}$ & \\
\hline \multirow{5}{*}{ Jiangsu set } & & $n=156$ & $n=706$ & & & $n=464$ & $n=494$ & & \\
\hline & $\mathrm{TT}$ & $133(85.3)$ & $629(89.1)$ & Reference & & $376(81.1)$ & $433(87.7)$ & Reference & \multirow{3}{*}{0.006} \\
\hline & TG & $20(12.8)$ & $76(10.8)$ & $1.25(0.68-2.29)$ & 0.468 & $85(18.3)$ & $60(12.1)$ & $\begin{array}{c}1.72 \\
(1.17-2.51)\end{array}$ & \\
\hline & GG & $3(1.9)$ & $1(0.1)$ & $\mathrm{NC}$ & & $3(0.6)$ & $1(0.2)$ & $\mathrm{NC}$ & \\
\hline & $\mathrm{TG}+\mathrm{GG}$ & $23(14.7)$ & 77 (10.9) & $1.42(0.79-2.53)$ & 0.240 & 88 (18.9) & $61(12.3)$ & $\begin{array}{c}1.76 \\
(1.21-2.57)\end{array}$ & 0.003 \\
\hline
\end{tabular}

Note: HBV, hepatitis B virus; HCC, hepatocellular carcinoma; OR, odds ratio; CI, confidence interval; NC, not calculated. ${ }^{a} \mathrm{HCC}$ case vs. chronic HBV carriers, data were calculated by logistic regression with adjustment for age, sex and smoking.

selection bias. As a result, it is crucial to confirm these observations in a population-based prospective study. Second, the statistical power for gene-covariate interaction analyses may be limited. Third, since the $P$ value for association between the GLB1 rs4678680 SNP and HCC risk in the current study are not less that $10^{-7}$, it is possible that these polymorphisms may not be identified by the aforementioned four large scale HCC GWAS in Chinese [7-10].

In summary, our study elucidated that the GLB1 rs4678680 polymorphism was associated with risk of HBV-related HCC in Chinese populations, highlighting the involvement of GLBI and cell senescence in etiology of HCC. 


\section{MATERIALS AND METHODS}

\section{Study subjects}

This study consisted of two case-control sets (Supplementary Table S1): (a) Shandong set: 1186 individuals with HBV-related HCC, sex- and age-matched ( \pm 5 years) 508 chronic HBV carriers were recruited at Shandong Cancer Hospital affiliated to Shandong University, Shandong Academy of Medical Sciences (Jinan, Shandong Province, China). (b) Jiangsu set: 620 HBV-related HCC individuals from Huaian No. 2 Hospital (Huaian, Jiangsu Province, China) and sex- and agematched 1200 chronic HBV carriers as controls. Cases and controls were recruited at Huaian No. 2 Hospital. The case-control sets has been reported previously [17]. A total of 56 pairs of $\mathrm{HCC}$ tissue specimens from $56 \mathrm{HCC}$ individuals recruited in this study. All HCC individuals received curative resection in Huaian No. 2 Hospital or Qianfoshan Hospital, Shandong University. Prior to the surgery, no HCC individuals received any local or systemic anticancer treatments. All subjects were ethnic Han Chinese. At recruitment, the written informed consent was obtained from each subject. This study was approved by the institutional Review Boards of Shandong Cancer Hospital, Qianfoshan Hospital and Huaian No. 2 Hospital.

\section{SNP genotyping}

The GLB1 rs4678680 polymorphism was analyzed by the MassArray system (Sequenom Inc., San Diego, California, USA). GLB1 rs4678680 PCR primers are 5'-ACGTTGGATGAGTCCAAGCCTGCTTTCTTC-3' (Forward) and 5'-ACGTTGGATGTCTGCCGAGTTGT TGCAAAG-3' (Reverse). GLB1 rs4678680 UEP_SEQ primer is $5^{\prime}$-cctcaTGCTTTCTTCCCTTTTCT-3'. GLB1 rs4678680 EXT1_SEQ primer is 5'-cctcaTGCTTTCT TCCCTTTTCTG-3'. GLB1 rs4678680 EXT2_SEQ primer is $5^{\prime}$-cctcaTGCTTTCTTCCCTTTTCTT-3'. A $15 \%$ blind, random sample of study subjects was genotyped in duplicates and the reproducibility was $100 \%$.

\section{Real-time analyses of GLB1 mRNA}

SYBR-Green real-time quantity PCR method was used to examine GLB1 mRNA levels in normal liver tissues as described previously [18-20]. Total cellular RNA was isolated and converted to cDNA using the ReverTra Ace qPCR RT Kit (TOYOBO). Relative gene expression quantitation for GLB1 and $\beta$-actin as an internal reference gene was carried out using the ABI 7500 real-time PCR system in triplicates. The primers used for GLB1 were 5'- GTCTATTCTTCTCCGCTCCT $-3^{\prime}$ and $5^{\prime}$ - TGTGCTCCATCAGTGGTAA - $3^{\prime}$; and for $\beta$-actin were $5^{\prime}$-GGCGGCACCACCATGTACCCT- ${ }^{\prime}$ and 5'-AGGGGCCGGACTCGTCATACT-3'. The expression of individual GLB1 mRNA measurements was measured relative to expression of $\beta$-actin mRNA using the method as described previously [21].

\section{Statistic analyses}

The differences in demographic variables and genotype distributions of the GLB1 rs4678680 SNP between cases and controls were examined via Pearson's $\chi^{2}$ test. The associations between genotypes of GLB1 rs4678680 and HBV-related HCC risk were estimated by ORs and their 95\% CIs computed by logistic regression models. All ORs were adjusted for age, sex, smoking or drinking status, where it was appropriate. Kruskal-Wallis one-way analysis of variance tests were performed to calculate GLB1 mRNA expression differences between different rs4678680 genotype carriers. A $P$ value of less than 0.05 was used as the criterion of statistical significance, and all statistical tests were two-sided. All analyses were performed using SPSS 16.0 (SPSS Inc.).

\section{CONFLICTS OF INTEREST}

The authors declare no competing financial interests.

\section{GRANT SUPPORT}

This work was supported by the National HighTech Research and Development Program of China (2015AA020950), National Natural Science Foundation of China (31271382), Natural Science Foundation of Shandong Province (ZR2015HL079, ZR2015HM040).

\section{REFERENCES}

1. Parkin DM, Bray F, Ferlay J, Pisani P. Global cancer statistics, 2002. CA Cancer J Clin. 2005; 55:74-108.

2. El-Serag HB, Rudolph KL. Hepatocellular carcinoma: epidemiology and molecular carcinogenesis. Gastroenterology. 2007; 132:2557-2576.

3. Poon D, Anderson BO, Chen LT, Tanaka K, Lau WY, Van Cutsem E, Singh H, Chow WC, Ooi LL, Chow P, Khin MW, Koo WH; Asian Oncology Summit. Management of hepatocellular carcinoma in Asia: consensus statement from the Asian Oncology Summit 2009. Lancet Oncol. 2009; 10:1111-1118.

4. Yeh FS, Yu MC, Mo CC, Luo S, Tong MJ, Henderson BE. Hepatitis B virus, aflatoxins, and hepatocellular carcinoma in southern Guangxi, China. Cancer Res. 1989; 49: 2506-2509.

5. Li Z, Guo Y, Zhou L, Ge Y, Wei L, Li L, Zhou C, Wei J, Yuan Q, Li J, Yang M. Association of a functional RAD52 genetic variant locating in a miRNA binding site with risk of HBV-related hepatocellular carcinoma. Mol Carcinog. 2015; 54:853-858. 
6. Pan W, Cheng G, Xing H, Shi J, Lu C, Wei J, Li L, Zhou C, Yuan Q, Zhou L, Yang M. Leukocyte telomere lengthrelated rs621559 and rs398652 genetic variants influence risk of HBV-related hepatocellular carcinoma. PLoS One. 2014; 9:e110863.

7. Jiang DK, Sun J, Cao G, Liu Y, Lin D, Gao YZ, Ren WH, Long XD, Zhang H, Ma XP, Wang Z, Jiang W, Chen TY, et al. Genetic variants in STAT4 and HLA-DQ genes confer risk of hepatitis B virus-related hepatocellular carcinoma. Nat Genet. 2013; 45:72-75.

8. Li S, Qian J, Yang Y, Zhao W, Dai J, Bei JX, Foo JN, McLaren PJ, Li Z, Yang J, Shen F, Liu L, Yang J, et al. GWAS identifies novel susceptibility loci on 6 p21.32 and 21q21.3 for hepatocellular carcinoma in chronic hepatitis B virus carriers. PLoS Genet. 2012; 8:e1002791.

9. Chan KY, Wong CM, Kwan JS, Lee JM, Cheung KW, Yuen MF, Lai CL, Poon RT, Sham PC, Ng IO. Genomewide association study of hepatocellular carcinoma in Southern Chinese patients with chronic hepatitis B virus infection. PLoS One. 2011; 6:e28798.

10. Zhang $\mathrm{H}$, Zhai Y, Hu Z, Wu C, Qian J, Jia W, Ma F, Huang W, Yu L, Yue W, Wang Z, Li P, Zhang Y, et al. Genome-wide association study identifies 1 p36.22 as a new susceptibility locus for hepatocellular carcinoma in chronic hepatitis B virus carriers. Nat Genet. 2010; 42:755-758.

11. Clifford RJ, Zhang J, Meerzaman DM, Lyu MS, $\mathrm{Hu}$ Y, Cultraro CM, Finney RP, Kelley JM, Efroni S, Greenblum SI, Nguyen CV, Rowe WL, Sharma S, et al. Genetic variations at loci involved in the immune response are risk factors for hepatocellular carcinoma. Hepatology. 2010; 52:2034-2043.

12. Phadke M, Krynetskaia N, Mishra A, Krynetskiy E. Accelerated cellular senescence phenotype of GAPDHdepleted human lung carcinoma cells. Biochem Biophys Res Commun. 2011; 411:409-415.

13. Caldwell ME, DeNicola GM, Martins CP, Jacobetz MA, Maitra A, Hruban RH, Tuveson DA. Cellular features of senescence during the evolution of human and murine ductal pancreatic cancer. Oncogene. 2012; 31:1599-1608.

14. Ewald JA, Desotelle JA, Church DR, Yang B, Huang W, Laurila TA, Jarrard DF. Androgen deprivation induces senescence characteristics in prostate cancer cells in vitro and in vivo. Prostate. 2013; 73:337-345.

15. Nam HY, Han MW, Chang HW, Kim SY, Kim SW. Prolonged autophagy by MTOR inhibitor leads radioresistant cancer cells into senescence. Autophagy. 2013; 9:1631-1632.

16. Wagner J, Damaschke N, Yang B, Truong M, Guenther C, McCormick J, Huang W, Jarrard D. Overexpression of the novel senescence marker $\beta$-galactosidase (GLB1) in prostate cancer predicts reduced PSA recurrence. PLoS One. 2015; 10:e124366.

17. Yang X, Yu D, Ren Y, Wei J, Pan W, Zhou C, Zhou L, Liu Y, Yang M. Integrative functional genomics implicates EPB41 dysregulation in hepatocellular carcinoma risk. Am J Hum Genet. DOI: http://dx.doi.org/10.1016/j.ajhg.2016.05.029.

18. Ge Y, Yan X, Jin Y, Yang X, Yu X, Zhou L, Han S, Yuan Q, Yang M. MiRNA-192 and miRNA-204directly suppress lncRNA HOTTIP and interrupt GLS1mediatedglutaminolysis in hepatocellular carcinoma. PLoS Genet. 2015; 11:e1005726.

19. Wang X, Ren Y, Wang Z, Xiong X, Han S, Pan W, Chen H, Zhou L, Zhou C, Yuan Q, Yang M. Down-regulation of 5S rRNA by miR-150 and miR-383 enhances c-Myc-rpL11 interaction and inhibits proliferation of esophageal squamous carcinoma cells. FEBS Lett. 2015; 589:3989-3997.

20. Wang X, Ren Y, Yang X, Xiong X, Han S, Ge Y, Pan W, Zhou L, Yuan Q, Yang M.miR-190a inhibits epithelialmesenchymal transition of hepatoma cells via targeting the long non-coding RNA treRNA. FEBS Lett. 2015; 589:4079-4087.

21. Lehmann U, Kreipe H. Real-time PCR analysis of DNA and RNA extracted from formalin-fixed and paraffin-embedded biopsies. Methods. 2001; 25:409-418. 